\title{
ISOLASI DAN IDENTIFIKASI BAKTERI PADA BENIH IKAN KERAPU CANTANG (Epinephelus sp.) DARI KOLAM PENDEDERAN BALAI PERIKANAN BUDIDAYA AIR PAYAU (BPBAP) SITUBONDO, JAWA TIMUR
}

\section{Isolation and Identification Bacteria on the Seeds Cantang Grouper (Epinephelus sp.) From Nursery Pond at Fisheries Center Brackish Water Aquaculture, Situbondo, East Java}

\author{
Dahlia $^{1 *}$, Hari Suprapto ${ }^{2}$ dan Rahayu Kusdarwati ${ }^{2}$ \\ ${ }^{1}$ Program Studi Budidaya Perairan, Fakultas Perikanan dan Kelautan, Universitas Airlangga, Surabaya \\ ${ }^{2}$ Departemen Manajemen Kesehatan Ikan dan Budidaya Perairan, Fakultas Perikanan dan Kelautan, Universitas \\ Airlangga, Surabaya \\ *dahlialia951@gmail.com
}

\begin{abstract}
Abstrak
Usaha budidaya ikan kerapu mempunyai prospek yang cukup baik untuk dikembangkan. Perkembangan produksi ikan kerapu cantang (Epinephelus sp.) menunjukkan kinerja yang cukup baik dengan peningkatan produksi rata-rata dari tahun 2010-2014 sebesar 9,61\%. Kendala yang sering dihadapi pada kegiatan budidaya ikan kerapu adalah terjadinya serangan bakteri, salah satunya bakteri patogen. Serangan bakteri patogen menimbulkan penurunan kualitas dan tingkat produksi pada usaha pembenihan maupun pendederan ikan kerapu, bahkan kematian serta kegagalan panen dapat terjadi. Penelitian ini dilaksanakan pada bulan Mei-Juni 2016. Penelitian dilakukan di laboratorium Kesehatan dan Lingkungan BPBAP Situbondo dan di Laboratorium Bakteri Balai Karantina Ikan Kelas I Juanda, Surabaya. Tujuan dari penelitian ini adalah untuk mengetahui jenis bakteri pada benih ikan kerapu cantang di kolam pendederan BPBAP Situbondo. Metode yang digunakan dalam penelitian ini adalah metode observasi. Observasi yaitu melakukan pengamatan secara langsung ke objek penelitian untuk melihat dari dekat kegiatan yang dilakukan. Data yang diperoleh dari penelitian isolasi dan identifikasi bakteri pada benih ikan kerapu cantang dianalisis secara deskriptif dan disajikan dalam bentuk gambar dan tabel. Hasil dari penelitian ini menunjukkan adanya bakteri pada benih ikan kerapu cantang dari kolam pendederan Balai Perikanan Budidaya Air Payau (BPBAP) Situbondo, Jawa Timur yaitu bakteri Vibrio alginolitycus, Vibrio harveyi dan Streptococcus iniae. Faktor terbesar yang mempengaruhi tertularnya bakteri pada benih ikan kerapu cantang antara lain adanya agen patogen dari pakan ikan rucah yang kualitasnya kurang bagus serta sifat kanibalisme ikan yang menyebabkan luka di permukaan tubuh ikan sehingga bakteri mudah masuk ke tubuh ikan dan menimbulkan infeksi.
\end{abstract}

Kata Kunci: Isolasi, Identifikasi, Bakteri, Benih, Epinephelus sp.

\begin{abstract}
The cultivation of grouper have good prospects for development. Production development cantang grouper (Epinephelus sp.) showed a good performance with an increase in average production from 2010-2014 amounted to $9.61 \%$. often mistake encountered on grouper aquaculture is the attack bacteria, one of which pathogenic bacteria. The attack pathogenic bacteria cause a decrease in the quality and level of production at the hatchery and nursery businesses grouper, as well as crop failure and even death can occur. This study was conducted in May-June 2016. The study was conducted in the laboratory of Health and Environment BPBAP Situbondo and in laboratory bacteria Fish Quarantine Class I Juanda, Surabaya. The purpose of this study was to know kind bacteria on the seeds cantang grouper from nursery pond at fisheries center brackish water aquaculture, Situbondo. The method used in this research is an observation method. Observation is a research direct to the object for a close look at the activities undertaken. The data obtained from the study of isolation and identification of bacteria on the seed grouper cantang analyzed descriptively and presented in the form of images and tables. The results of this study indicate the presence of bacteria on the seed cantang grouper fish at nursery pond At Fisheries Center Brackish Water Aquaculture, Situbondo, East Java is Vibrio alginolitycus, Vibrio harveyi and Streptococcus iniae. The biggest factor affecting the transmission of bacteria on the seeds of grouper cantang among others feeding trash fish quality is not good and cannibalistic nature of fish that causes sores on the body surface of the fish so that the bacteria easily enter the body of the fish then infect it.
\end{abstract}


Keywords: Isolation, Identification, Bacteria, Brood, Epinephelus Sp.

\section{PENDAHULUAN}

Ikan kerapu merupakan salah satu komoditas unggulan budidaya di Indonesia disamping tiga komoditas lainnya seperti udang, ikan nila, dan rumput laut. Produksi ikan kerapu pada tahun 2010-2014 menunjukkan kenaikan produksi rata-rata per tahun sebesar 9,61\%. Kementerian Kelautan dan Perikanan pada tahun 2014 menargetkan volume produksi budidaya sebesar 16,8 juta ton, dalam hal ini Kementerian Kelautan dan Perikanan mengadakan penyediaan benih ikan kerapu yang bermutu di Unit Pelaksana Teknis dan Unit Pembenihan Skala Rumah Tangga (KKP, 2014).

Salah satu inovasi teknologi dari Unit Pelaksana Teknis dan Direktorat Jenderal Perikanan Budidaya adalah mengkawinsilangkan (hibridisasi) ikan kerapu macan (Epinephelus fuscoguttatus) dan ikan kerapu kertang (Epinephelus lanceolatus) menghasilkan benih hibrida ikan kerapu cantang di Balai Budidaya Air Payau Situbondo. Benih hibrida ikan kerapu cantang menambah diversifikasi spesies serta mempunyai prospek budidaya yang berpeluang untuk meningkatkan produksi perikanan. Pemantapan produksi benih hibrida ikan kerapu cantang sangat diperlukan untuk menghasilkan benih yang mempunyai kuantitas dan kualitas yang baik dan pada akhirnya diharapkan dapat membantu kebutuhan benih pada kegiatan budidaya (Ismi dkk., 2013).

Kendala yang sering dihadapi pada kegiatan budidaya ikan kerapu adalah terjadinya serangan bakteri. Serangan bakteri dapat menimbulkan penurunan tingkat kuantitas dan kualitas produksi pada usaha pembenihan maupun pendederan ikan kerapu, bahkan kematian serta kegagalan panen dapat terjadi (Hatmanti, 2008). Salah satu contoh benih ikan kerapu cantang yang pernah mengalami kematian berada di kolam pendederan BPBAP Situbondo. Kematian benih tidak terjadi secara massal namun terjadi secara bertahap dan terus-menerus dalam hal ini sangat merugikan budidaya dalam kolam pendederan. Kematian benih ikan kerapu juga terjadi pada Balai Sea Farming di Perairan Pulau Semak Daun dan Karang Congkak Kepulauan Seribu, Jakarta bahwa benih ikan kerapu yang didederkan terinfeksi penyakit dengan gejala klinis adanya borok pada tubuh, penggeripisan ekor serta warna kulit yang memutih dan menyebabkan kematian mencapai $80 \%$ dari total populasi.

Ikan budidaya sangat rentan terhadap infeksi mikroorganisme patogen seperti virus, bakteri, jamur dan parasit. Menurut Shickney (2000) bakteri yang pernah ditemukan pada golongan ikan kerapu adalah Vibrio sp, Streptococcus sp dan Flexibacter sp. Pengendalian penyakit bakteri pada budidaya ikan kerapu dapat dilakukan dengan mengetahui jenis bakteri yang menyerang pada ikan. Salah satu cara untuk mengetahui jenis bakteri apa saja yang menyerang pada budidaya ikan kerapu adalah dilakukannya identifikasi bakteri.

\section{METODOLOGI}

\section{Waktu dan Tempat}

Penelitian ini telah dilaksanakan di laboratorium Kesehatan dan Lingkungan BPBAP Situbondo dan di Laboratorium Bakteri Balai Karantina Ikan Kelas I Juanda, Surabaya pada bulan Mei-Juni 2016.

\section{Materi Penelitian}

Peralatan Penelitian

Alat-alat yang digunakan dalam penelitian ini antara lain alat tulis, nampan, cawan petri, tabung reaksi, jarum ose, cool box, objek glass, erlenmeyer, gelas ukur, timbangan analitik, magnetis stirer, mikroskop, kertas label, kapas, tisu, paper oxsidase, aluminium foil, sectio set, spatula, bunsen, oven, autoclave, laminar air flow, inkubator dan refrigerator. Alat untuk pengukuran kualitas air meliputi : 
$\mathrm{pH}$ meter, DO meter, termometer, refraktometer.

Bahan Penelitian

Bahan-bahan yang digunakan dalam penelitian ini adalah benih ikan kerapu cantang, alkohol 70\%, media TSA 2\%, media TSIA (Triple Sugar Iron Agar), LIA (Lysine Iron Agar), MIO (Motility Indol Ornitin), O/F (Oksidatif/Fermentatif), MRVP, Simmons Citrate, media selektif, media gula (glukosa, laktosa, sukrosa, maltosa, arbinosa, manitol, dan inositol), antibiotik novobiocin $30 \mathrm{mg}$, larutan perioksida 3\%, Methyl Red, $\mathrm{KOH} 40 \%$, minyak imersi, serta bahan uji pewarnaan Gram (crystal violet, lugol, alkohol 95\%, safranin dan aquades).

\section{Metode Penelitian}

Dalam penelitian ini meggunakan metode observasi. Observasi yaitu melakukan pengamatan secara langsung ke objek penelitian untuk melihat dari dekat kegiatan yang dilakukan (Susanti, 2010). Observasi dalam penelitian ini dilakukan terhadap berbagai hal yang berhubungan dengan isolasi dan identifikasi bakteri pada benih ikan kerapu cantang dari kolam pendederan BPBAP Situbondo.

\section{Prosedur Kerja}

Dalam penelitian ini pengambilan sample ikan menggunakan metode purposive sampling. Metode purposive sampling yaitu mengambil sampel sesuai dengan karakteristik yang ditentukan oleh peneliti. Benih ikan yang dijadikan sampel merupakan ikan yang memiliki panjang 8,8-11 cm sebanyak 20 ekor dan menunjukkan gejala terinfeksi bakteri seperti tubuh lemah, timbul borok, bercak merah (erythema) pada pangkal sirip, mata menonjol (exophthalmia), pendarahan (hemorrhage) pada insang, mulut dan tubuh.

Mengisolasi bakteri dilakukan di dalam laminary air flow dengan sumber isolat adalah permukaan kulit ikan dan ginjal. Isolasi dilakukan dengan mengam- bil lendir di luka pada permukaan kulit ikan menggunakan jarum ose steril kemudian menggoreskan ke media TSA $2 \%$ secara zig zag. Hasil isolasi bakteri diinkubasi pada suhu antara $26-30^{\circ} \mathrm{C}$ selama 24-48 jam.

Pemurnian bakteri dilakukan dengan mengambil bakteri yang terdapat pada media yang memililiki bentuk, warna, dan ukuran koloni yang seragam kemudian menginokulasi berulang pada media tumbuh bakteri (media TSA $2 \%$ ).

Pengamatan morfologi koloni bakteri dilakukan setelah mendapatkan biakan murni. Pengamatan morfologi koloni bakteri dengan melihat warna, bentuk, tepian, permukaan koloni (elevasi) secara langsung dari media tumbuh bakteri.

Pewarnaan Gram merupakan salah satu teknik identifikasi bakteri yang sangat penting dalam menentukan jenis bakteri. Prosedur pewarnaan bakteri yaitu membuat ulasan bakteri pada objek glass kemudian dikeringkan dengan cara difiksasi diatas api. Kemudian di lakukan pewarnaan dengan larutan kristal violet, larutan lugol, alkohol 95\% dan safranin. Preparat yang sudah kering kemudian ditetesi dengan minyak imersi untuk diamati menggunakan mikroskop dengan perbesaran 1000x.

Uji biokimiawi merupakan suatu cara yang dilakukan untuk mengetahui reaksi kimia yang terjadi di dalam tubuh mikroorganisme. Hasil uji biokimiawi dapat digunakan untuk mengidentifikasi suatu mikroorganisme. Menurut (Buller, 2004) uji biokimiawi yang dipakai dalam kegiatan identifikasi bakteri antara lain: uji katalase, oksidase, O/F, MIO, TSIA, gelatin, LIA, MR-VP, Citrate dan uji gula.

Pengamatan kualitas air yang meliputi suhu, $\mathrm{pH}$, oksigen terlarut, amonia dan salinitas menggunakan termometer, pH meter, DO meter, dan refraktometer. Pengamatan kualitas air dilakukan karena kualitas air merupakan media hidup ikan yang dapat mempengaruhi kesehatan dan pertumbuhan. 


\section{Parameter Penelitian}

Parameter utama yang diamati adalah jenis bakteri pada benih ikan kerapu cantang dari kolam pendederan BPBAP Situbondo. Parameter penunjang yang diamati adalah kualitas air meliputi $\mathrm{pH}$, suhu, amonia, oksigen terlarut dan salinitas.

\section{Analisis Data}

Data hasil isolasi dan identifikasi bakteri pada benih ikan kerapu cantang dianalisis secara deskriptif dan disajikan dalam bentuk gambar dan tabel. Data yang didapat akan dibandingkan dengan buku identifikasi bakteri "Cowan and Steel's Manual for the Identification of Medical Bacteria" dan "Buller, Bacteria from Fish and Other Aquatic: A Practical Identification Manual”.

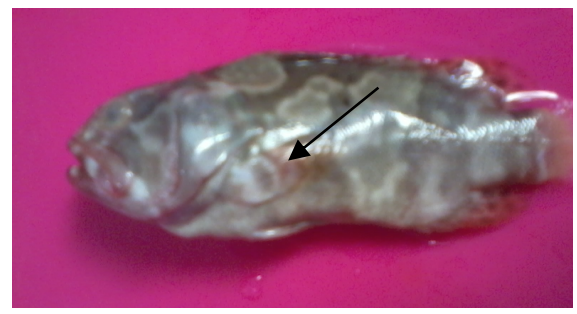

a

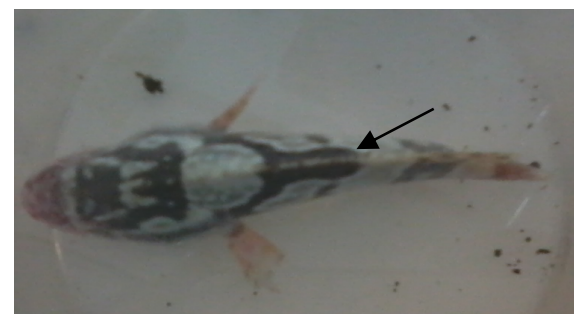

c

\section{HASIL DAN PEMBAHASAN Isolasi Bakteri dari Benih Ikan Kerapu Cantang}

Pada penelitian dilakukan kegiatan isolasi dan identifikasi bakteri pada benih ikan kerapu cantang. Benih yang dijadikan sampel pada penelitian adalah benih ikan kerapu cantang yang diduga terinfeksi bakteri dan menunjukkan gejala klinis terinfeksi penyakit bakteri. Sampel benih ikan kerapu cantang yang terinfeksi penyakit bakteri ditunjukkan adanya bercak merah di permukaan tubuh, mata menonjol, warna tubuh pucat, ikan lemah (menyendiri) dan bagian ekor yang geripis. Gambar ikan yang yang terinfeksi bakteri dapat dilihat pada Gambar 1.1.

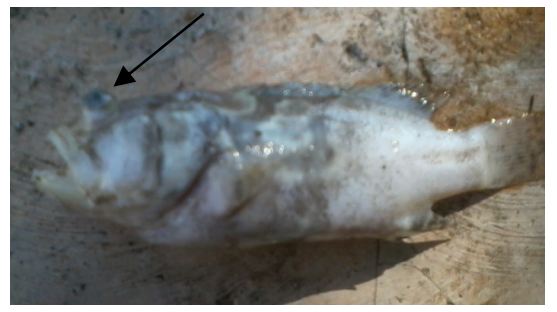

b

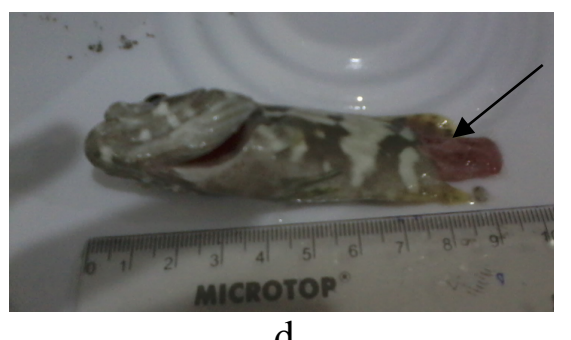

d

Gambar 1.1 Gejala klinis benih ikan kerapu cantang:
(a) Bercak merah pada tubuh ikan
(c) Warna tubuh ikan pucat
(b) Mata menonjol
(d) Sirip geripis

Sampel benih ikan kerapu cantang yang diambil dari dua kolam pendederan BPBAP Situbondo sebanyak dua puluh ekor. Isolasi dengan mengambil organ target luka di permukaan kulit dan ginjal dan menggoreskan pada media TSA $2 \%$ secara zig-zag (streak plate) menggunakan ose steril. Isolasi dengan metode streak plate memiliki kelebihan dibandingkan dengan metode lainnya yaitu koloni bakteri yang dihasilkan merupakan koloni tunggal, bakteri yang kontaminan mudah dibedakan, dan dapat membuat goresan dengan pola tertentu. Pengisolasian awal didapatkan isolat bakteri sebanyak 40 . 
Dari 40 isolat bakteri yang didapatkan kemudian dilakukan pemurnian bakteri pada media TSA $2 \%$. Setelah pemurnian dilakukan penyeleksian berdasarkan kesamaan morfologi koloni bakteri dari segi warna, bentuk, elevasi dan tepian dalam hal ini didapatkan 3 isolat bakteri pada benih ikan kerapu cantang. Ketiga isolat bakteri yang didapatkan lalu diberi kode A, B, C. Pemberian kode ini didasarkan pada perbedaan morfologi koloni tiap isolat bakteri. Hasil uji pewarnaan bakteri Gram positif dan Gram negatif secara mikroskopis dapat dilihat pada Gambar 1.2. Berikut merupakan hasil pengamatan morfologi koloni bakteri dan sel bakteri pada benih ikan kerapu cantang dari kolam pendederan.

Tabel 1.1 Morfologi Koloni Bakteri dan Sel Bakteri pada Benih Ikan Kerapu Cantang dari Kolam Pendederan.

\begin{tabular}{|c|c|c|c|c|c|c|}
\hline \multirow{2}{*}{$\begin{array}{l}\text { Kode } \\
\text { isolate }\end{array}$} & \multicolumn{4}{|c|}{ Morfologi koloni } & \multicolumn{2}{|c|}{ Morfologi sel } \\
\hline & Bentuk & Tepi & Elevasi & Warna & Bentuk & Gram \\
\hline A & Menyebar & Berlekuk & Flat & $\begin{array}{l}\text { Kuning } \\
\text { kecoklatan }\end{array}$ & Bacil & - \\
\hline B & Menyebar & Berlekuk & Raised & $\begin{array}{l}\text { Kuning } \\
\text { kecoklatan }\end{array}$ & Bacil & - \\
\hline $\mathrm{C}$ & Bulat & Rata & Raised & Kuning & Coccus & + \\
\hline
\end{tabular}

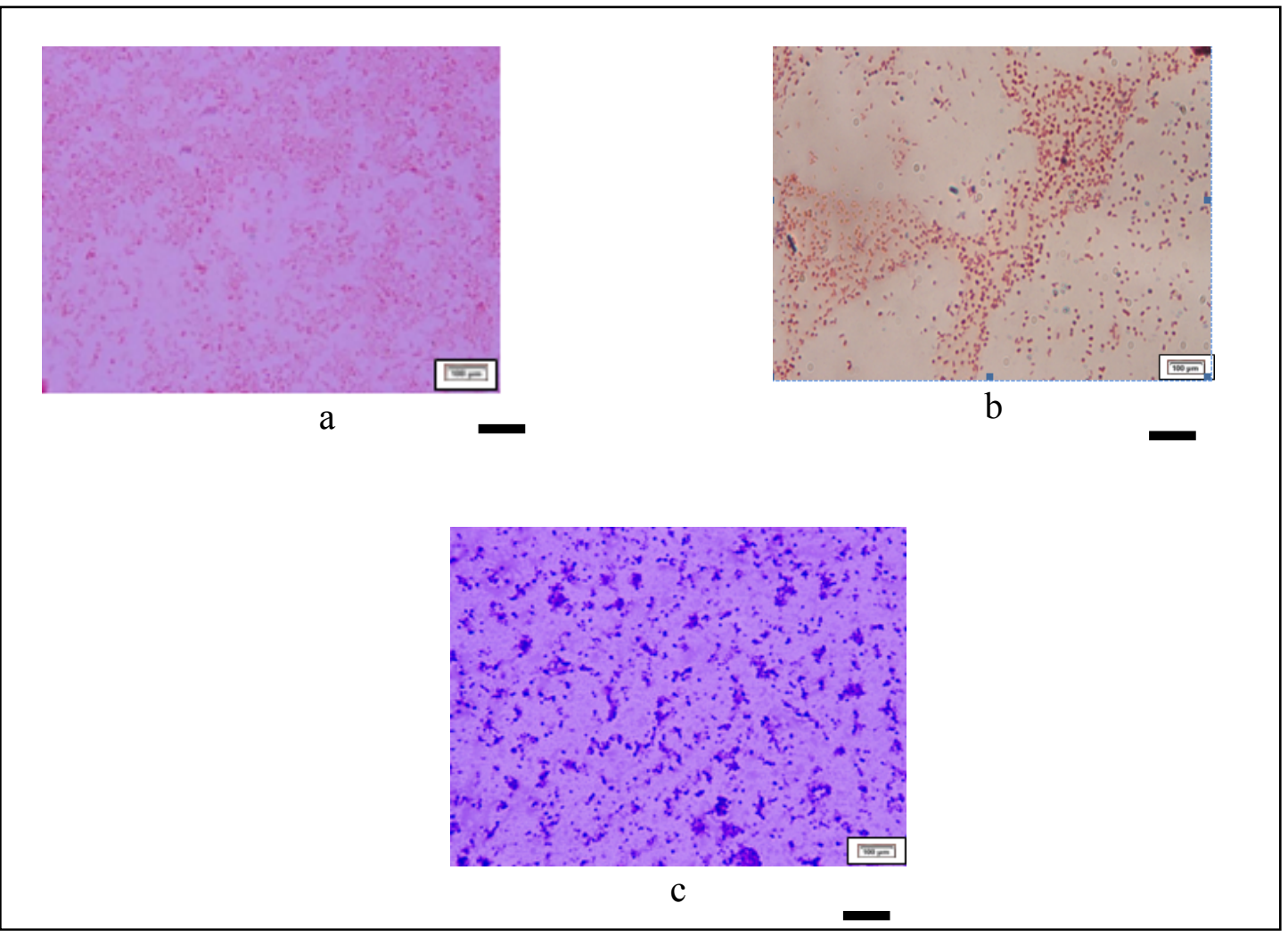

Gambar 1.2 Hasil Pengamatan Isolat Bakteri secara Mikroskopis:

a) Kode isolat A, berbentuk bacil, Gram negatif dengan ukuran $100 \mu \mathrm{m}$

b) Kode isolat B, berbentuk bacil, Gram negatif dengan ukuran $100 \mu \mathrm{m}$

c) Kode isolat C, berbentuk coccus, Gram positif dengan ukuran $100 \mu \mathrm{m}$

(Sumber: Dokumetasi pribadi, 2016) 
Pada uji pewarnaan Gram, semua bakteri Gram positif berwarna biru atau violet hal ini dikarenakan bakteri Gram positif mempunyai lapisan peptidoglikan yang tebal dan menahan kristal violet selama pewarnaan gram, sedangkan bakteri Gram negatif berwarna merah karena lapisan peptidoglikan yang tipis yang menyebabkan kristal violet terbuang setelah pemberian alkohol dan pada tahap selan- jutnya pemberiaan safranin memberikan warna merah pada bakteri Gram negatif.

\section{Hasil Uji Biokimiawi}

Dari ketiga isolat bakteri A, B, C yang telah dimurnikan dan diuji morfologi sel selanjutnya dilakukan uji biokimiawi. Hasil ketiga isolat bakteri yang telah di uji biokimiawi dapat dilihat pada tabel berikut ini.

Tabel 1.2 Hasil Perbandingan Uji Biokimiawi Isolat A,B,C dengan Pustaka

\begin{tabular}{|c|c|c|c|c|c|c|}
\hline Karakteristik & $\begin{array}{c}\text { Isolat } \\
\text { A }\end{array}$ & $\begin{array}{c}\text { Vibrio } \\
\text { alginolyticus } \\
\text { (Cowan, 2003) }\end{array}$ & $\begin{array}{c}\text { Isolat } \\
\text { B }\end{array}$ & $\begin{array}{c}\text { Vibrio } \\
\text { harveyi } \\
\text { (Cowan, 2003) }\end{array}$ & Isolat $\mathrm{C}$ & $\begin{array}{c}\text { Streptococcus } \\
\text { Iniae } \\
\text { (Cowan, 2003) }\end{array}$ \\
\hline Oksidase & + & + & + & + & - & - \\
\hline Katalase & + & + & + & + & - & - \\
\hline $\mathrm{O} / \mathrm{F}$ & $\mathrm{F}$ & $\mathrm{F}$ & $\mathrm{F}$ & $\mathrm{F}$ & $\mathrm{F}$ & $\mathrm{F}$ \\
\hline $\mathrm{TSIA}-\mathrm{H}_{2} \mathrm{~S}$ & - & - & - & - & - & - \\
\hline LIA & + & + & + & + & - & - \\
\hline Motil & + & + & + & + & - & - \\
\hline Indol & + & + & + & + & - & - \\
\hline Ornitin & + & + & + & + & - & - \\
\hline MR & + & + & + & + & + & + \\
\hline VP & + & - & - & - & - & - \\
\hline Simmon & + & - & - & + & + & - \\
\hline Citrate & & & & & & \\
\hline Novobiocin & $\mathrm{S}$ & $\mathrm{S}$ & $\mathrm{S}$ & $\mathrm{S}$ & $\mathrm{R}$ & $\mathrm{R}$ \\
\hline Gelatin & + & - & - & + & + & - \\
\hline Glukosa & + & + & + & + & + & + \\
\hline Maltosa & + & + & + & + & + & + \\
\hline Sukrosa & + & + & + & + & - & + \\
\hline Arbinosa & - & - & - & - & s- & - \\
\hline Manitol & + & + & + & + & + & + \\
\hline Inositol & - & - & - & - & - & - \\
\hline
\end{tabular}

Keterangan $=\mathrm{S} / \mathrm{R}$ (Sensitif/Resisten), O/F (Oksidatif/fermentatif), +/- (Positif/Negatif)

Ciri-ciri utama suatu bakteri yang perlu diketahui dalam mengkarakterisasi bakteri adalah melalui beberapa uji morfologi dan uji biokimiawi. Pengujian biokimiawi yang dilakukan dalam penelitian ini meliputi uji oksidase, katalase, $\mathrm{O} / \mathrm{F}$, TSIA, LIA, MIO, MR, VP, Citrate, gelatin dan uji gula (glukosa, maltosa, sukrosa, arbinosa, manitol dan inositol).

Dari hasil pengamatan morfologi dan uji biokimiawi yang dibandingkan dengan buku Cowan and Steel's, Manual for the Identification of Medical Bacteria" dan "Buller, Bacteria from Fish and Other Aquatic: A Practical Identification Manual) didapatkan kecocokan karakteristik dengan bakteri Vibrio alginolyticus. Kode isolat bakteri A memiliki kecocokan dengan bakteri Vibrio alginolyticus sebesar $94 \%$. Kode isolat bakteri B memiliki kecocokan dengan bakteri Vibrio harveyi sebesar $89 \%$. Kode isolat bakteri C memiliki kecocokan dengan bakteri Streptococcus iniae sebesar $84 \%$.

Deskriptif bakteri Vibrio alginolitycus pada proses identifikasi termasuk 
bakteri Gram negatif, bentuk morfologi sel bacil (batang), warna koloni kuning kecoklatan, menyebar, bagian tepi berlekuk serta elevasi flat (ketinggian sama medium), dan uji biokimiawi bersifat oksidase dan katalase positif, bersifat fermentatif, motil, indol positif, ornitin positif, gelatin positif, MR dan VP positif, uji gula glukosa, maltosa, sukrosa, manitol positif sedangkan arbinosa inositol negatif. Bakteri Vibrio alginolitycus sangat umum ditemukan pada perairan payau dan laut. Menurut Desrina dkk., (2006) dari beberapa spesies bakteri yang sering ditemukan pada ikan kerapu yang sakit adalah bakteri Vibrio alginolitycus. Ikan kerapu yang sakit memiliki gejala klinis seperti bercak merah pada permukaan tubuh, mulut dan sirip, benih ikan terlihat lemah, berenang menyendiri, nafsu makan berkurang, penggeripisan sirip, serta adanya luka di permukaan kulit.

Deskriptif bakteri Vibrio harveyi pada proses identifikasi hampir mirip dengan bakteri Vibrio alginolitycus. Perbedaan bakteri Vibrio alginolitycus dan Vibrio harveyi terletak pada uji biokimia MR/VP dan morfologi koloni yaitu berwarna kuning kecoklatan, menyebar, bagian tepi berlekuk serta elevasi raised (ketinggian nyata terlihat). Menurut Irianto (2005) bakteri Vibrio harveyi bersifat sebagai bakteri oportunistik dan merupakan bakteri yang sangat ganas serta berbahaya pada budidaya ikan laut karena dapat bertindak sebagai patogen primer dan sekunder. Sebagai patogen primer bakteri masuk tubuh ikan melalui kontak langsung ikan, sedangkan sebagai patogen sekunder bakteri menginfeksi ikan dengan adanya luka akibat organisme lain/gesekan ikan yang dipelihara dengan kepadatan tinggi.

Padat tebar benih ikan kerapu cantang dikolam pedederan BPBAP Situbondo tergolong baik karena kepadatan benih ikan yang berukuran $7-10 \mathrm{~cm}$ sekitar 100 ekor $/ \mathrm{m}^{3}$ dalam kategori optimum. Menurut Mursitorini dan Ramdhani (2013) kepadatan optimum benih ikan kerapu pada fase pendederan sekitar 150-200 ekor dari volume kolam 1,5 $\mathrm{m}^{3}$ dengan ukuran ikan 9-12 cm. Gejala klinis benih ikan kerapu cantang yang terserang bakteri Vibrio harveyi mirip dengan gejala klinis benih ikan kerapu cantang yang terserang bakteri Vibrio alginolitycus. Menurut Schubert (1987) bakteri yang memilliki genus Vibrio yang menginfeksi ikan laut pada stadia benih selain tubuh ikan lemah juga tubuh memproduksi lendir yang berlebihan dan pada tingkat akut sirip punggung dan sirip ekor geripis.

Keganasan bakteri genus vibrio berkaitan dengan produksi siderofor (agen penyapit zat besi) yang berfungsi mengikat zat besi dari darah inang (Desrina dkk, 2006). Zat besi dalam sel darah merah berperan dalam memproduksi hemoglobin, hemoglobin berfungsi dalam mengangkut oksigen dari insang ke jaringan tubuh untuk proses metabolisme sel, jika proses metabolisme sel terganggu hal ini dapat mempengaruhi sistem kerja organ sehingga mengakibatkan suatu keadaan abnormal didalam tubuh (penyakit). Angka (1990) juga menambahkan bahwa salah satu sifat dari bakteri Gram negatif adalah dapat melisiskan hemoglobin dalam hal ini bakteri genus vibrio termasuk bakteri gram negatif yang dapat melisiskan hemoglobin dan mempengaruhi proses metabolisme sel. Kadar hemoglobin yang rendah dapat menjadi salah satu indikasi pada ikan atas terjadinya infeksi bakteri. Bakteri Vibrio pada media selektif Thiosulfat Citrat Bile Sucrose (TCBS) memperlihatkan warna kuning, bulat hal ini sesuai dengan pendapat Buller (2004).

Deskriptif bakteri Streptococcus iniae pada proses identifikasi termasuk bakteri Gram positif bentuk morfologi sel coccus, warna koloni kuning, bulat, bagian tepi rata serta elevasi raised (ketinggian nyata terlihat), dan uji biokimiawi bersifat oksidase dan katalase negatif, bersifat fermentatif, nonmotil, indol negatif, ornitin negatif, gelatin positif, MR positif dan VP negatif, uji gula glukosa, maltosa, dan manitol positif sedangkan sukrosa, arbi- 
nosa dan inositol negatif. Genus Streptococcus sp pada medium padat memiliki warna koloni kuning, bulat transparan, elevasi raised (ketinggian nyata terlihat) dan Gram positif (Nagazawa, 2004). Bakteri Streptococcus iniae dalam penelitian telah dilakukan penanaman bakteri dalam media diferensial Blood Agar (BA) untuk melihat tipe bakteri dalam menghemolisis darah. Hasil dari penanaman bakteri pada media diferensial menunjukkan bakteri bersifat beta hemolisis hal ini sesuai dengan Buller (2004) Beta hemolisis di media diferensial Blood Agar (BA) terlihat zona bening sekeliling koloni hal ini dikarenakan terjadi lisis sel darah merah dilengkapi kerusakan dan penggunaan hemoglobin oleh mikroorganisme. Beta hemolisis di media diferensial Blood Agar (BA) dapat dilihat pada Gambar 1.3

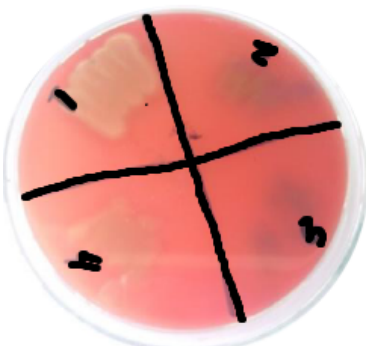

Gambar 1.3 Beta hemolisis pada media diferensial

Menurut Irianto (2005) penularan penyakit Streptococcosis dapat melalui kontak langsung dengan inang yang sakit, ketahanan tubuh benih ikan yang masih rentan, dan pakan yang terkontaminasi. Pakan yang diberikan pada benih ikan kerapu cantang pada saat penelitian adalah ikan rucah dengan membuang isi perut dan kepala. Pemberian pakan ikan rucah pada benih menggunakan metode ad satiation, yakni memberi makan ikan sekenyangnya hal ini bertujuan menghindari sifat kanibalisme antar benih ikan. Kanibalisme antar benih dapat menjadi pemicu luka pada ikan dan masuknya bakteri ke dalam tubuh ikan. Ikan rucah memiliki kandungan nutrisi yang sangat tinggi serta memiliki harga yang murah bila dibandingkan dengan pellet namun ketersediaan ikan rucah tergantung musim dan tidak semua kualitas ikan rucah bagus hal ini yang menyebabkan ikan bisa tertular bakteri. Menurut Novriadi (2014) pemberian pakan ikan rucah bisa menjadi perantara sumber penyakit yang bisa menular pada ikan budidaya walaupun pemberian membuang isi perut dan kepala karena bagian tersebut mengandung banyak patogen.

Ditemukannya bakteri Vibrio alginolitycus, Vibrio harveyi, dan Streptococcus iniae pada benih ikan kerapu cantang dari kolam merupakan indikasi lemahnya ketahanan tubuh benih ikan kerapu cantang. Benih ikan yang digunakan dalam penelitian merupakan benih ikan yang memiliki ukuran 8,8-10 cm. Menurut Azhar (2011) ukuran benih ikan kerapu 8,8-11 cm merupakan ukuran titik rawan untuk terjadinya infeksi vibriosis. Persentase bakteri yang ditemukan dari 20 sampel benih ikan kerapu cantang yang telah diidentifikasi diketahui Vibrio alginolitycus sekitar 35\%, bakteri Vibrio harveyi sekitar 27,5\%, bakteri Streptococcus iniae sekitar 30\%. Ditemukan bakteri Vibrio alginolitycus dan Vibrio harveyi pada penelitian ini sama dengan bakteri yang ditemukan pada penelitian Hidayat (2014) yaitu terdapat bakteri Vibrio alginolitycus dan Vibrio harveyi dari ikan kerapu sunu yang sakit. Jumlah persentase tertinggi dari bakteri yang ditemukan pada benih ikan kerapu cantang adalah bakteri Vibrio alginolitycus karena menurut Rahayu (2009) bakteri Vibrio alginolitycus merupakan jenis bakteri yang paling patogen pada ikan kerapu dibandingkan dengan jenis bakteri lainnya.

Penyakit pada ikan muncul akibat ketidakseimbangan antara ikan sebagai inang, patogen (mikroorganisme penyebab penyakit) serta lingkungan. Faktor lingkungan yang dapat menimbulkan penyakit adalah kualitas air. Hasil pengukuran kualitas air dari kolam pendederan BPBAP Situbondo dapat dilihat pada tabel berikut 
Tabel 1.3 Kualitas Air dari Kolam Pendederan BPBAP Situbondo.

\begin{tabular}{lcccccc}
\hline Waktu & Tempat & $\begin{array}{c}\text { Suhu } \\
\left({ }^{\circ} \mathrm{C}\right)\end{array}$ & $\mathrm{pH}$ & $\begin{array}{c}\text { Oksigen } \\
\text { Terlarut }(\mathrm{ppm})\end{array}$ & $\begin{array}{c}\text { Salinitas } \\
(\mathrm{ppt})\end{array}$ & $\begin{array}{c}\text { Amoniak } \\
(\mathrm{ppm})\end{array}$ \\
\hline Pagi & Kolam 1 & 30 & 8 & 5,5 & 32 & 0,003 \\
& Kolam 2 & 28 & 8 & 5,3 & 32 & 0,031 \\
Siang & Kolam 1 & 28,1 & 8 & 5,5 & 31 & 0,009 \\
& Kolam 2 & 31 & 8 & 5,6 & 31 & 0,047 \\
Sore & Kolam 1 & 30 & 8 & 4,8 & 32 & $<0,001$ \\
& Kolam 2 & 31 & 8 & 5,7 & 32 & $<0,001$ \\
\hline
\end{tabular}

Penyakit pada ikan muncul akibat ketidakseimbangan antara ikan sebagai inang, patogen (mikroorganisme penyebab penyakit) serta lingkungan. Faktor lingkungan yang dapat menimbulkan penyakit adalah kualitas air. Pengujian sampel air dari kolam pendederan BPBAP Situbondo menunjukkan kualitas air di kolam pendederan tergolong dalam kategori ideal karena memiliki suhu antara $28-31^{\circ} \mathrm{C}$, salinitas 31-32 ppt, amoniak $<0,5 \mathrm{ppm}, \mathrm{pH}$ 8 serta kandungan oksigen terlarut 4,8- 5,7 ppm hal ini sesuai sesuai dengan pendapat Aprilia (2008) kualitas air yang cocok untuk pertumbuhan ikan kerapu yaitu temperatur $28-32^{\circ} \mathrm{C}$, salinitas berkisar $30-32$ ppt, amoniak <0,5 ppm, pH antara 6,5-9 dan kandungan oksigen terlarut berkisar $>5$ ppm. Oksigen memegang peranan penting sebagai indikator kualitas perairan dalam kelangsungan hidup ikan karena berperan untuk pernafasan dan metabolisme ikan. Menurunnya kadar oksigen terlarut dalam suatu perairan dapat mengurangi nafsu makan ikan yang pada akhirnya menyebabkan pertumbuhan terganggu serta menjadikan ikan stres sehingga sistem imun menjadi menurun. Pada saat itu, serangan penyakit akan mudah masuk ke dalam tubuh ikan, baik berupa bakteri ataupun parasit Shafrudin dkk., (2006).

\section{KESIMPULAN DAN SARAN Kesimpulan}

Dari penelitian ini ditemukan bakteri pada benih ikan kerapu cantang dari kolam pendederan Balai Perikanan Budidaya Air Payau (BPBAP) Situbondo, Jawa Timur yaitu bakteri Vibrio alginolitycus,
Vibrio harveyi dan Streptococcus iniae. Faktor terbesar yang mempengaruhi tertularnya bakteri pada benih ikan kerapu cantang antara lain adanya agen patogen dari pakan ikan rucah yang kualitasnya kurang bagus serta sifat kanibalisme ikan yang menyebabkan luka di permukaan tubuh ikan sehingga bakteri mudah masuk ke tubuh ikan dan menimbulkan infeksi.

\section{Saran}

Untuk meningkatkan kualitas dan kuantitas produksi benih ikan kerapu cantang, maka perlu dilakukan penelitian lebih lanjut mengenai tambahan bahan imunostimulant/vaksin yang dapat meminimalisir bakteri pada benih ikan kerapu cantang terutama bakteri yang merugikan budidaya.

\section{DAFTAR PUSTAKA}

Aprilia, T. 2008. Aplikasi Pengkayaan Rotifera dengan Asam Amino Bebas Untuk Larva Kerapu Bebek Cromileptes altivelis. Skripsi. Program Studi Teknologi dan Manajemen Akuakultur. Fakultas Perikanan dan Ilmu Kelautan. Institut Pertanian Bogor. hal 11.

Angka, S.L. 1990. The Pathology of The Walking Catfish, Clarias batrachus Infected Intraperitoneally with Aeromonas hydrophila. Asian Fish. Journal Sciences. 3:343-351

Azhar, F. 2011. Vibriosis pada Pendederan Ikan Kerapu Bebek Cromileptes altivelis di Pulau Payung Kepulauan Seribu. Skripsi. Fakultas 
Perikanan dan Ilmu Kelautan. Institut Pertanian Bogor. hal. 43.

Balai Budidaya Air Payau. 2012. Ikan Kerapu Cantang Hibrida Antara Ikan Kerapu Cantang Macan Betina dengan Ikan Kerapu Kertang Jantan. Balai Budidaya Air Payau Situbondo. http://bbapsitubondo.com. Diakses Tanggal 13 Januari 2016. hal. 6.

Buller, N.B. 2004. Bacteria from Fish and Other Aquatic: A Practical Identification Manual. CABI Publising $\mathrm{CAB}$ International Wallingford Oxford shire OX108DE. United Kingdom. pp. 161.

Cowan, S. T. 2003. Cowan and Steel's Manual for the Identification of Medical Bacteria, 2 ${ }^{\text {nd }}$ edn. Cambridge University Press, Cambridge. hal. 23.

Desrina, T. Arief, Ambariyanto dan S.Susiani. 2006. Uji Keganasan Bakteri Vibrio pada Ikan Kerapu Macan. Jurnal Ilmu Kelautan. 11(3) : 125

Hatmanti, A., A. Nuchsin dan Y. Darmayati. 2008. Studi Penyakit Bakterial pada Budidaya Ikan Kerapu dan Bakteri Penghambatnya di Perairan Teluk Lampung. Jurnal Akuakultur Indonesia, 7(1): 51-58.

Hidayat, A. S. 2014. Isolasi dan Identifikasi Bakteri Vibrio sp dari Ikan Kerapu Sunu (Plectropomus leoparddus). Jurnal Teknosains. hal. 8.

Irianto, A. 2005. Patologi Ikan Teleostei. Gadjah Mada University Press. Yogyakarta. hal. 256.

Ismi, S., Y.N. Asih, dan D. Kusumawati. 2013. Peningkatan Produksi dan Kualitas Benih Ikan Kerapu Melalui Program Hibridisasi. Jurnal Ilmu dan Teknologi Kelautan Tropis. hal. 333-342.
Kementerian Kelautan dan Perikanan. 2014. Laporan Kinerja Kementerian. Jakarta. hal.176.

Mursitorini, E dan P. Ramdhani. 2013. Penyakit Ikan Kerapu. Loka Pemeriksaan Penyakit dan Lingkungan. Direktorat Jenderal Kementerian Kelautan dan Perikanan Budidaya. hal. 4.

Nagazawa, K and E.R.C. Lacierda. 2004. Disease Cultured Groupers. Southeast Asian Fisheries Development Center Aquaculture Department. Government of Japan Trust Fund. pp. 19.

Rahayu, A.M. 2009. Keragaman dan Keberadaan Penyakit Bakterial dan Parasitik Benih Kerapu Macan (Epinephelus fuscoguttatus) di Karamba Jaring Apung Balai Sea Farming Kepulauan Seribu. Skripsi. Fakultas Perikanan dan Ilmu Kelautan. Institut Pertanian Bogor. Jakarta. hal. 25.

Novriadi, R. 2014. Penyakit Ikan Air Laut di Indonesia. Kementerian Kelautan dan Perikanan, Direktorat Jenderal Perikanan Budidaya, Direktorat Kesehatan Ikan dan Lingkungan. hal.28.

Shafrudin, D., Yuniarti dan M. Setiawati, 2006. Pengaruh Kepadatan Benih Ikan Lele Dumbo (Clarias sp.) terhadap Produksi Pada Sistem Budidaya dengan Pengendalian Nitrogen Melalui Penambahan Tepung Terigu. Jurnal Akuakultur Indonesia 5 (2) : 137-147.

Schubert, G. 1987. Fish Diseases a Complete Introduction. T.F.H. Publications Inc. USA. pp. 125.

Shickney, R. R., 2000. Encyclopedia of Aquaculture. John Wiley and Sons. Inc. pp. 418-421.

Susanti, M.N.I. 2010. Statistika Deskriptif dan Induktif. Graha Ilmu. Yogyakarta. hal. 122. 